\title{
Relationships among Parent-Child Relationship Beliefs and Obedience Behaviors in Different Parental Emotional Blackmail tacties
}

Szu-Yu Chen ${ }^{1} \&$ Chih-Fen Wei ${ }^{2}$

Department of Education, University of Taipei ${ }^{1}$

Department of Psychology and Counseling, University of Taipei ${ }^{2}$

\section{Introduction}

The purpose of this study is to explore the effect of parent-child relationship beliefs emotional

blackmail tactic on obedience behavior in career planning/marriage decision-making situations.

Susan Forward(1998) indicated that emotional blackmail was defined as the strategy people use to force their family members, partners and close friends to do what they want. The effect of emotional blackmail could be moderated by children's belief about life origin

Chen (2019) proposed two kinds of parent-child relationship beliefs: the belief of life origin stated that parents were origins of children 's live(the belief of life origin); the unity view of life stated that parents and their children were unity(the unity view of life).

\section{Hypotheses}

H1: The positive correlations among the two kinds of parent-child relationship beliefs (BLO \& UVL) and obedience behaviors.

H2 : BLO \& UVL as moderators among situations and obedience behaviors.

H3: BLO \& UVL as moderators among parental emotional blackmail tactics and obedience behaviors.

\section{Method}

Convenience sampling was conducted and recruited 251 participants, including 62 males and 189 females, 106 married and 137 unmarried. The average age of participants was 36.87 years old.

Research design was a $2 \times 2 \times 2 \times 2$ completely between-subject design. The independent variables included two kinds of parent-child beliefs (the belief of life origin(BLO)/the unity view of life(UVL)), situations (career planning/marriage), and parental emotional blackmail tactics (evoking child 's debt for parents / breaking up with child). The dependent variables were obedience behaviors (verbal obedience/ decision obedience).

\section{Result}

The Pearson product-moment correlation showed that there were positive correlations between BLO and verbal obedience, UVL and verbal obedience, UVL and decision obedience.

The multivariate analysis showed that UVL X Situations positively predicted verbal obedience and decision obedience $\left(F_{(1,235)}=4.13,6.06, p<.05\right)$. UVL positively predicted decision obedience $\left(\mathrm{F}_{(1,}\right.$ $\left.{ }_{235}=4.78, p<.05\right)$. Emotional Blackmail tactics significantly predicted decision obedience $\left(F_{(1,235)}=\right.$ $6.27, p<.01)$, breaking up with children would be more likely than evoking children's debt for parents to induce decision obedience.

\section{Result}

According the results of simple main effects. In marriage situation, individuals with high unity view of life were more likely to perform verbal obedience and decision obedience than those with low $\operatorname{UVL}\left(F\left(_{1,247)}=6.83\right.\right.$, $11.83, p<0.025)$

Verbal obedience and decision obedience of low UVL group were higher in career situation than in marriage situation $\left(F_{(1,247)}=4.99,3.99, p<.05\right)$.

Table

\begin{tabular}{lcccc}
\multicolumn{1}{l}{ Means, standard deviations and correlations } \\
& $M(S D)$ & BLO & UVL & $\begin{array}{c}\text { Verbal } \\
\text { obedience }\end{array}$ \\
\hline BLF & $4.87(.82)$ & - & & \\
UVF & $3.60(.85)$ & $.40^{* *}$ & - & \\
Verbal obedience & $4(1.16)$ & $.13^{*}$ & $.16^{*}$ & - \\
Decision obedience & $3(.98)$ & -.001 & $.19^{* *}$ & $.29^{* *}$ \\
\hline
\end{tabular}

Note $*$ indictes $p<05$; ** indicates $p<01$

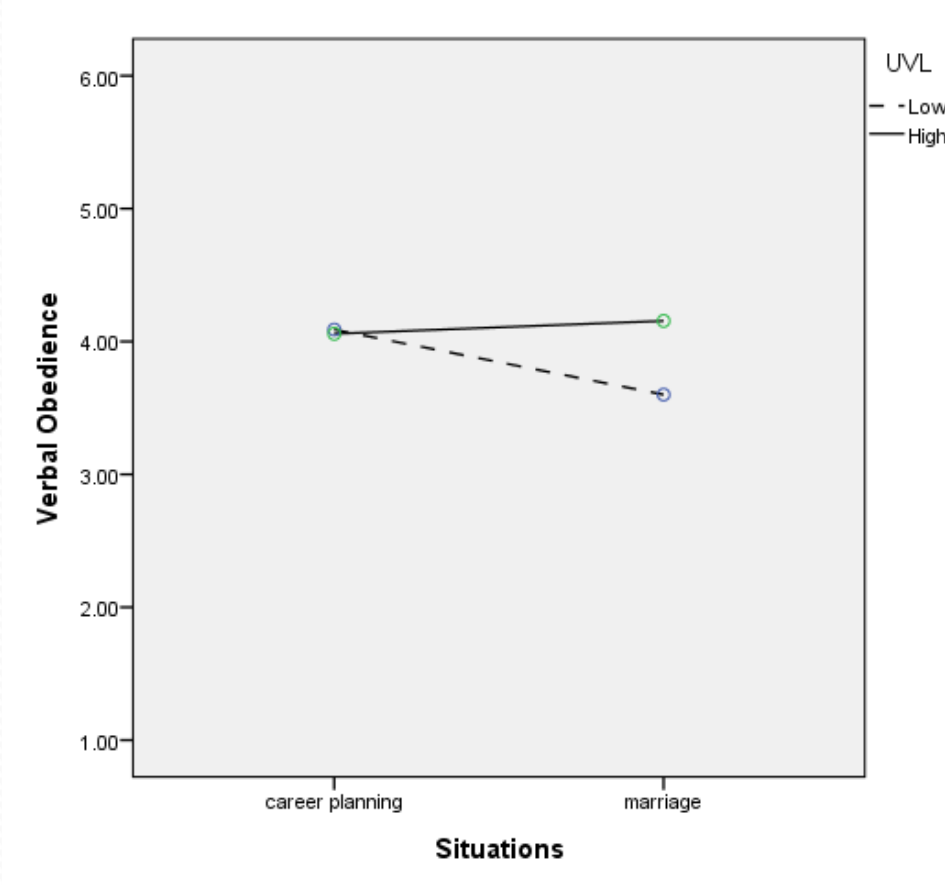

Figure 1: Interaction offect of UVL and signions on verbal obedience

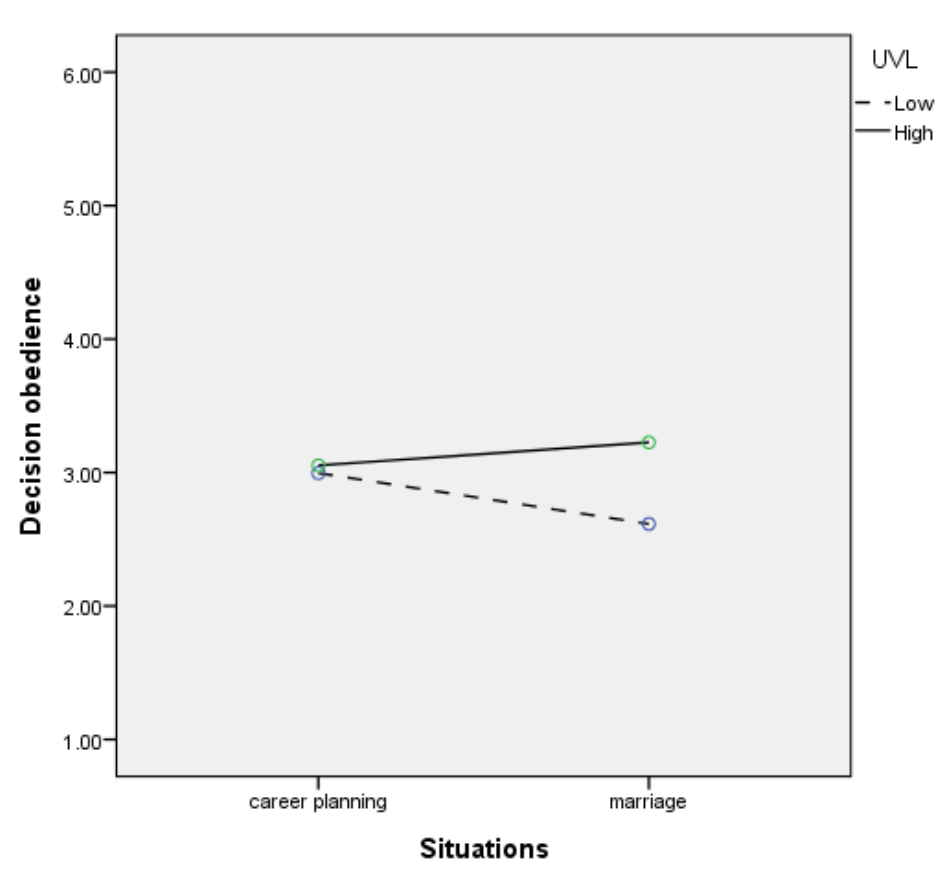

Figure 2: Interaction effect of UVL and situations on lecision obedience

\section{Conclusion}

1. Only UVL as moderator among situations and obedience behaviors.

2. When parents adopt emotional blackmail tactics to prevent children marry someone they don't like, children with high unity view of life were more likely to obedience to their parents than those with low unity view of life. 